\title{
Knockdown delta-5-desaturase in breast cancer cells that overexpress COX-2 results in inhibition of growth, migration and invasion via a dihomo- $\gamma$-linolenic acid peroxidation dependent mechanism
}

\author{
Yi Xu ${ }^{1+}$, Xiaoyu Yang ${ }^{1+}$, Tao Wang ${ }^{1}$, Liu Yang ${ }^{2}$, Yu-Ying $\mathrm{He}^{3}$, Keith Miskimins ${ }^{4}$ and Steven Y. Qian ${ }^{1 *}$ (i)
}

\begin{abstract}
Background: Cyclooxygenase-2 (COX-2), the inducible COX form, is a bi-functional membrane-bound enzyme that typically metabolizes arachidonic acid (downstream $\omega-6$ fatty acid) to form 2-series of prostaglandins known to be involved in cancer development. Overexpression of COX-2 has been found in a majority of breast carcinomas, and has also been associated with increased severity and the development of the metastasis. Our lab recently demonstrated that COX-2 can also metabolize dihomo-y-linolenic acid (DGLA, a precursor of $\omega-6$ arachidonic acid) to produce an anti-cancer byproduct, 8-hydroxyoctanoic acid (8-HOA) that can inhibit growth and migration of colon and pancreatic cancer cells. We thus tested whether our strategy of knocking down delta-5-desaturase (D5D, the key enzyme that converts DGLA to arachidonic acid) in breast cancer cells overexpressing COX-2 can also be used to promote 8-HOA formation, thereby suppressing cancer growth, migration, and invasion.
\end{abstract}

Methods: SiRNA and shRNA transfection were used to knock down D5D expression in MDA-MB 231 and 4 T1 cells (human and mouse breast cancer cell lines expressing high COX-2, respectively). Colony formation assay, FITC Annexin V/PI double staining, wound healing and transwell assay were used to assess the effect of our strategy on inhibition of cancer growth, migration, and invasion. GC/MS was used to measure endogenous 8-HOA, and western blotting was performed to evaluate the altered key protein expressions upon the treatments.

Results: We demonstrated that D5D knockdown licenses DGLA to inhibit growth of breast cancer cells via promoting formation of 8-HOA that can inhibit histone deacetylase and activate cell apoptotic proteins, such as procaspase 9 and PARP. Our strategy can also significantly inhibit cancer migration and invasion, associated with altered expression of MMP-2/-9, E-cadherin, vimentin and snail. In addition, D5D knockdown and DGLA supplementation greatly enhanced the efficacy of 5-fluorouracil on breast cancer growth and migration.

Conclusions: Consistent to our previous studies on colon and pancreatic cancer, here we demonstrate again that the high level of COX-2 in breast cancer cells can be capitalized on inhibiting cancer growth and migration. The outcome of this translational research could guide us to develop new anti-cancer strategy and/or to improve current chemotherapy for breast cancer treatment.

Keywords: COX-catalyzed DGLA peroxidation, delta-5-desaturase, D5D knockdown MDA-MB 231 and 4 T1 cells, breast cancer growth, migration and invasion

\footnotetext{
* Correspondence: steven.qian@ndsu.edu

${ }^{\dagger}$ Equal contributors

'Department of Pharmaceutical Sciences, North Dakota State University,

Fargo, ND 58108, USA

Full list of author information is available at the end of the article
}

\section{Biomed Central}

(c) The Author(s). 2018 Open Access This article is distributed under the terms of the Creative Commons Attribution 4.0 International License (http://creativecommons.org/licenses/by/4.0/), which permits unrestricted use, distribution, and reproduction in any medium, provided you give appropriate credit to the original author(s) and the source, provide a link to the Creative Commons license, and indicate if changes were made. The Creative Commons Public Domain Dedication waiver (http://creativecommons.org/publicdomain/zero/1.0/) applies to the data made available in this article, unless otherwise stated. 


\section{Highlights}

- High level of COX-2 could be exploited to inhibit breast cancer cell growth and migration

- 8-hydroxyoctanoic acid, generated from D5D knockdown and DGLA supplementation, serves HDAC inhibitor, causes DNA damage, and suppresses breast cancer growth, migration and invasion

- D5D knockdown warranties DGLA's anti-cancer activity and improves anti-cancer effect of chemotherapy in breast cancer cells

\section{Background}

Breast cancer is the leading cause of cancer death worldwide in women and about $90 \%$ deaths from breast cancer are a consequence of metastasis. A variety of therapeutic and nutritional approaches including chemotherapy, targeted therapy, and $\omega-3$ fatty acid dietary manipulation have been studied for breast cancer treatment [1-12]. $\omega-6 \mathrm{~s}$ fatty acids which are inevitable and more pervasive in our daily diet (ratio of $\omega-6 \mathrm{~s}$ vs. $\omega-3 \mathrm{~s}$ in traditional western diet is between $\sim$ 10:1 and 30:1) have received much less research attention in cancer therapy, mainly due to deleterious metabolites (2series prostaglandins, e.g., PGE2) formed from cyclooxygenase (COX)-catalyzed peroxidation of arachidonic acid (AA, a downstream $₫-6$ fatty acid) [13-19]. In contrast, COX-2 substrates, including eicosapentaenoic acid and docosahexaenoic acid (two $\omega-3$ fatty acids) and dihomo- $\gamma$-linolenic acid (perhaps an exceptional $\omega-6$ fatty acid), have shown some inhibitory effects on cancer cell growth and metastasis, most likely due to their competition with AA for the COX-2 peroxidation to limit PGE2 formation [6-12, 20-23].

COX is a bi-functional membrane bound and lipid peroxidizing enzyme with two isoforms, a constitutive form COX-1 and an inducible form COX-2. COX-2 can be readily induced by cellular stresses, growth factors, cancer promoters, and pro-inflammatory signals [24-30]. Although a few conflicting reports exist, high COX-2 expression has been found in the majority of breast carcinomas, $\sim 63 \%-85 \%$ of premalignant-stage breast cancers cases (e.g., ductal carcinoma in situ), and $\sim 87 \%$ of metastatic breast cancer [24-30]. Induction of COX-2 has also been reported in breast cancer associated fibroblasts that make up the bulk of cancer stroma to promote breast cancer initiation and progression [29]. Among many putative mechanisms by which $\omega-6 \mathrm{~s}$ can modulate the carcinogenic process, COX-2-catalyzed arachidonic acid peroxidation to form PGE2 is the most salient one [15-19]. PGE2 has been shown to be involved in breast cancer growth, invasion, metastasis as well as in the development of chemo-drug resistance [15-19]. A variety of COX-2 inhibitors and $\omega-3$ fatty acid supplements aiming to limit PGE2 formation from COX-2-mediated AA peroxidation have been extensively investigated as a complementary treatment for cancer therapy [31-38]. However, COX-2 inhibitors not only are ineffective in general, but also suffer from critical safety issues in patients such as increased risks of cardiovascular disease and gastrointestinal tract injury [39-42].

Our lab has previously identified both common as well as exclusive free radicals generated from COX-catalyzed peroxidation of AA and dihomo- $\gamma$-linolenic acid (DGLA, an intermediate precursor of AA), using a HPLC/ESR/ MS combined method along with spin trapping technique $[43,44]$. The different structural moiety in DGLA leads to the formation of a distinct byproduct 8hydroxyoctanoic acid (8-HOA) from COX-2-mediated DGLA peroxidation. More recently, we demonstrated that 8-HOA can serve as a histone deacetylase inhibitor (HDACi) to inhibit growth and metastasis of colon (HCA7 colony 29 and HT-29) and pancreatic (BxPC-3) cancer cells overexpressing COX-2 [45-49]. Our novel strategy combining genetic knockdown of delta-5-desaturase (D5D), the key enzyme for converting DGLA to AA, with DGLA supplementation has been shown to suppress cancer cell growth and metastasis via not only suppressing PGE2 generation from AA (limited by D5D downregulation), but also by reserving more DGLA to form 8-HOA. Unlike the classic COX-2 inhibition strategy in cancer treatment in which high expression of COX-2 is the problem, we actually now take advantage of high COX-2 expression in cancer cells for the inhibition of cancer growth and metastasis. In addition, our strategy enhances efficacies of many chemo-drugs [45-49].

In the present study, we further extend our strategy to the inhibition of breast cancer growth, migration and invasion. The promoted formation of 8-HOA from COX2- mediated DGLA peroxidation manipulated by D5D knockdown can significantly inhibit breast cancer cell growth and metastasis, as well as improve the efficacy of 5-fluorouracil, a commonly used chemo-drug to treat breast cancer. The outcomes from our work shed the light on the development of complementary $\omega$-6-based diet care strategies in combination with chemo-drugs for breast cancer treatment.

\section{Methods \\ Cell lines and materials}

The human breast cancer cell line MDA-MB 231 (ATCC, catalog \# HTB-26) and mouse breast cancer cell line 4 T1 (ATCC, catalog \# CRL2539), both with high level of COX-2 expression, were generous gift from Dr. Keith Miskimins (Cancer Biology Research Center, Sanford Research, Sioux Falls, SD). The cells were grown in Dulbecco's Modified Eagle's Medium supplemented with $10 \%$ fetal bovine serum (Thermo Fisher Scientific, UT, USA). Cells were cultured in an incubator $\left(37^{\circ} \mathrm{C}\right)$ with $5 \% \mathrm{CO}_{2}$ and a $95 \%$ humidified atmosphere. Ethics 
approval and informed consent are not needed for the use of the cell lines in our study.

DGLA was obtained from Nu-Chek-Prep (MN, USA). 8-HOA, 5-FU, CelLytic ${ }^{\mathrm{Tw}}$ lysis reagent, and D5D primary antibody produced from rabbit were acquired from Sigma-Aldrich (MO, USA). D5D-targeting siRNA (catalog 4,390,825), negative control siRNA (NC-si) and Lipofectamine $^{\text {ts }}$ RNAiMAX transfection reagent were purchased from Life Technologies (NY, USA). GlutaMAX ${ }^{\text {mi }}$ OptiMEM reduced serum medium, Pierce ECL western blot substrates, NE-PER ${ }^{\mathrm{m}}$ nuclear and cytoplasmic extraction reagents were bought from Thermo Fisher Scientific (MA, USA). Annexin V Apoptosis Detection Kit I was obtained from BD Pharmingen ${ }^{\text {Tw }}$ (NJ, USA). HDAC activity assay kit was purchased from BioVision (CA, USA). COX-2 primary antibody produced in rabbit was acquired from Abcam (MA, USA). $\gamma \mathrm{H}_{2} \mathrm{AX}$ primary antibody was purchased from Bethyl Laboratories (TX, USA). All other primary and secondary antibodies were bought from Cell Signaling (MA, USA). X-ray film was purchased from Phoenix Research Products (NC, USA).

Using BLOCK-IT ${ }^{\mathrm{m}}$ RNAi Designer (http://www.invitrogen.com/rnai), DNA oligos encoding D5D-targeted shRNA were designed with sequence of TGCTGTAATCATCCAGGCCAAGTCCA GTTTTGGCCACTGACTGACTGGACTTGCTGGATGATTA (top strand) and CCTGTAAT CATCCAGCAAGTCCAGTCAGTCAGTCAGTGGCCAAAACTGGACTTGGCCTGGATGAT-

TAC (bottom strand). The oligos were then synthesized and purchased from Integrated DNA Technologies (IA, USA). pcDNA ${ }^{\mathrm{ma}}$ 6.2-GW/EmGFP-miR vector was purchased from Invitrogen (NY, USA).

\section{SiRNA transfection}

Breast cancer cells MDA-MB 231 and 4 T1 were seeded at $3.0 \times 10^{5}$ cells per well in a 6-well plate and incubated overnight. After removing cell culture medium, cells in each well were washed with phosphate buffered saline (PBS) and treated with $1.0 \mathrm{~mL}$ of transfection mixture containing $10 \mu \mathrm{L}$ Lipofectamine $^{\mathrm{T}}$ RNAiMAX transfection reagent and D5D siRNA (final concentration $150 \mathrm{nM}$ ) diluted in GlutaMAX $^{\text {ma }}$ Opti-MEM reduced serum medium. Following 6 h transfection, Dulbecco's Modified Eagle's Medium supplemented with $10 \%$ fetal bovine serum was to replace the Opti-MEM reduced serum medium. After $48 \mathrm{~h}$ incubation, the transfected cells were prepared for western blot evaluation or subjected to further treatments followed by colony formation assay, cell cycle distribution and apoptosis analysis, and GC/MS measurement. Cancer cells transfected with a nontarget siRNA were used as negative controls in all described experiments.

\section{ShRNA transfection}

ShRNA D5D transfections of MDA-MB 231 and 4 T1 cells were also conducted, typically for assessment of cancer cell migration and invasion study. It takes more than $48 \mathrm{~h}$ to grow cancer cells to $90 \%$ confluency for wound healing assay, thus, shRNA transfected cell lines were used instead of siRNA transfected cells to guarantee suppressed D5D activities during the experiment. Briefly, we transfected D5D shRNA into MDA-MB 231 and $4 \mathrm{~T} 1$ cells to create stable D5D knockdown cell lines. The DNA oligos encoding D5D-targeted shRNA were cloned into $\mathrm{pcDNA}^{\mathrm{mix}}$ 6.2-GW/EmGFP-miR vector and transformed into E. coli. The shRNA expressed vector was extracted and transfected into cells using XtremeGENE HP DNA Transfection Reagent (Roche). Stable D5D knockdown MDA-MB 231 and 4 T1 cell lines were selected using blasticidin. The stable D5D knockdown cell lines were used for assessing cancer cell migration and invasion upon different treatments (e.g., DGLA and 5-FU). Cancer cells transfected with negative control shRNA (NC-sh) were used as controls.

\section{Colony formation assay}

Cell growth response upon 8-HOA, DGLA and chemo drug treatment was assessed by colony formation assay as described elsewhere [47-49]. Briefly, wild type-D5D (wt-D5D) cells, D5D-knockdown (D5D-KD) cells or negative siRNA transfected control (NC-si) cells were seeded at 1000 cells per well into a 6-well plates, and then exposed to $48 \mathrm{~h}$ treatment with 8-HOA, DGLA, 5$\mathrm{FU}$, or their combination. After washing with PBS, the cells were re-incubated with fresh medium for another 10 days, followed by fixing with $10 \%$ neutral buffered formalin and staining with $0.05 \%$ crystal violet solution. The plates were washed with water and left to dry, then cell colonies in each well were counted using a microcopy. The plate efficiency was calculated as total number of colonies counted in each well divided by total number of cells seeded. Cell survival fraction was calculated as the percentage of plate efficiency from treatment group $v s$. the plate efficiency from vehicle control groups.

\section{Wound healing assay}

Wound healing assay was used to assess cancer cell migration upon treatments of 8-HOA and DGLA. Negative control shRNA transfected (NC-sh) or shRNA transfected D5D-KD MDA-MB 231 and $4 \mathrm{~T} 1$ cells were seeded $1.0 \times 10^{6}$ cells per well (6-well plate). After the cells reached $90 \%$ confluence, a wound was simulated on the cell monolayer by scratching with a sterile pipette tip and each well was then washed with phosphate buffered saline (PBS) to eliminate dislodged cells. The medium was changed to medium with $1.0 \%$ fetal bovine serum. The cells were subjected to different treatment 
(e.g. 8-HOA and DGLA) up to $48 \mathrm{~h}$. The wound area was measured using Image-J software $(\mathrm{NIH}$, Bethesda, MD, USA). The percentages of wound areas were calculated at $24 \mathrm{~h}$ and/or $48 \mathrm{~h}$ vs. controls ( $0 \mathrm{~h}$ time point) in each group.

\section{Transwell assay}

Transwell migration assays were performed to assess cancer cell migration upon treatments with DGLA and chemo-drugs in transwell chamber with the non-coated membrane (24-well insert, pore size: $8 \mathrm{~mm}$, Corning, Life Sciences). Treated with DGLA or chemo-drugs for $48 \mathrm{~h}$, shRNA transfected D5D-KD MDA-MB 231 and 4 T1 cells were trypsinized and counted. $5 \times 10^{4}$ cells from each treatment were plated in the top chamber and incubated overnight to allow the cells to attach. Medium without serum was added to the upper chamber, and the medium containing $10 \%$ fetal bovine serum was added in the lower chamber. The cells were fixed in $10 \%$ neutral buffered formalin solution for $30 \mathrm{~min}$ and stained with $0.05 \%$ crystal violet solution for $30 \mathrm{~min}$, and the cells that migrated or invaded through the pores to the lower surface of the inserts were counted under an inverted microscope. For invasion assays, same treatments were also used, except that the transwell inserts were coated with Matrigel.

\section{Measurement of endogenous 8-HOA in cancer cells}

8-HOA (in its derivatized form with pentafluorobenzyl bromide, PFB-Br) generated from D5D-KD MDA-MB 231 and $4 \mathrm{~T} 1$ cells and negative control cells treated by DGLA were measured via GC/MS as described elsewhere [47-50]. Briefly, $3.0 \times 10^{5}$ cells were seeded overnight in each well of 6-well plates, transfected with D5D siRNA or its negative control, and received $100 \mu \mathrm{M}$ of DGLA treatment (in ethanol, final volume $<0.1 \%$ ) up to $48 \mathrm{~h}$. At each experimental time points, the cells were scratched and collected in $1.0 \mathrm{~mL}$ culture medium, and mixed with $500 \mu \mathrm{L}$ of methanol containing internal standard (hexanoic acid), $50 \mu \mathrm{L}$ of $1.0 \mathrm{~N} \mathrm{HCl}$, and $3.0 \mathrm{~mL}$ of dichloromethane. After vortex for 30s, the mixture was centrifuged at $3000 \mathrm{rpm}$ for $4 \mathrm{~min}$ and the dichloromethane layer was collected. The samples were subject to the same extraction again, and all organic layers of two extractions were combined and evaporated to dryness. The extracted analytes were reconstituted in $50 \mu \mathrm{L}$ of $1.0 \%$ diisopropylethylamine in acetonitrile and derivatized with $50 \mu \mathrm{L}$ of $1.0 \%$ PFB-bromide in acetonitrile at $37{ }^{\circ} \mathrm{C}$ for $30 \mathrm{~min}$. The acetonitrile was then evaporated to dryness, and the residue was reconstituted in $100 \mu \mathrm{L}$ dichloromethane for GC/MS analysis.

About $2.0 \mu \mathrm{L}$ of the sample solution was injected into an Agilent 7890A gas chromatograph. The GC oven temperature (from $60{ }^{\circ} \mathrm{C}$ to $300{ }^{\circ} \mathrm{C}$ ) is programmed at $25^{\circ} \mathrm{C} / \mathrm{min}$, while keeping the injector and transfer line at $280{ }^{\circ} \mathrm{C}$. A MS selective detector was used for quantitative analysis with a source temperature of $230{ }^{\circ} \mathrm{C}$. The formation of 8-HOA (in its PFB derivative) was quantified in selected ion monitoring mode for the base peak of 8 -HOA-PFB derivative $(\mathrm{m} / \mathrm{z} 181)$ by comparing it with the base peak of internal standard (hexanoic acidPFB derivative) using an internal standard curve.

\section{Cell apoptosis assay}

Cell apoptosis of D5D-KD MDA-MB 231 and 4 T1 cells as well as their negative controls, upon treatments of DGLA, 5-FU, and the combination, was analyzed using the Annexin V Apoptosis Detection Kit I (BD Pharmingen ${ }^{\mathrm{Tm}}, \mathrm{NJ}$, USA) according to the manufacturer's instruction [47-49]. Briefly, $3.0 \times 10^{5}$ cells were seeded overnight in each well of 6-well plates, transfected with D5D siRNA or the negative control, and treated with DGLA, 5-FU or their combination for $48 \mathrm{~h}$. Then the experimental cells were harvested and re-suspended in $1 \times$ binding buffer at a concentration of $1.0 \times 10^{6}$ cells $/ \mathrm{ml}$. The cell suspension $(\sim 100 \mu \mathrm{l})$ was then treated with $5.0 \mu \mathrm{L}$ each of FITC Annexin V and PI solution, gently vortexed, incubated for $15 \mathrm{~min}$ at $25{ }^{\circ} \mathrm{C}$ in the dark, and finally mixed with $400 \mu \mathrm{L}$ of $1 \times$ binding buffer. The apoptotic cell population was determined on an Accuri C6 flow cytometer within 1 h. 10,000-cell events were counted for each sample. Unstained cells, the cells stained with FITC Annexin $\mathrm{V}$ only and PI only, were all used to set up compensation and quadrants. Data was analyzed by FlowJo (TreeStar, Ashland, OR, USA).

\section{HDAC activity assay}

HDAC activity was performed using HDAC activity assay kit according to manufacturer's instructions. Briefly, after cells directly treated with 8-HOA and D5D-KD along with DGLA, nuclear proteins were extracted with NE-PER ${ }^{\mathrm{T} M}$ nuclear and cytoplasmic extraction reagents. Nuclear extracts were incubated with HDAC substrate at $37{ }^{\circ} \mathrm{C}$ for $1 \mathrm{~h}$ and then lysine developer was added to the mixture and incubated for $30 \mathrm{~min}$ at $37{ }^{\circ} \mathrm{C}$. The plate was read at $405 \mathrm{~nm}$ on a microplate reader. The HDAC activity in MDA-MB 231 and 4 T1 cells without 8-HOA treatment was set to $100 \%$.

\section{Western blotting}

Western blot was used to assess the expression of D5D, COX-2, $\gamma \mathrm{H}_{2} \mathrm{AX}$, acetyl-histone $\mathrm{H} 3(\mathrm{AcH} 3)$ as well as proteins involved in apoptosis, migration and invasion in MDA-MB 231 and 4 T1 cells upon treatments [47-49]. The cells seeded in a 6-well plate were transfected with D5D siRNA/shRNA or negative control siRNA/shRNA, 
and treated with DGLA and/or 5-FU for $48 \mathrm{~h}$. The proteins were extracted from experimental cells and then loaded into $10 \%$ SDS-PAGE gels. The gel was ran at a constant current of $30 \mathrm{~mA}$ for $1 \mathrm{~h}$ followed by protein transferring at a constant voltage of $80 \mathrm{~V}$ for $2 \mathrm{~h}$ on ice. The membranes were incubated with primary antibodies (1:600 dilution) overnight at $4{ }^{\circ} \mathrm{C}$ and horseradish peroxidase-conjugated secondary antibody (1:2000 dilution) for $1 \mathrm{~h}$ at room temperature with continuous rocking. The membranes were then incubated in ECL western blot substrates for $1 \mathrm{~min}$, and exposed to X-ray film. Luminescent signals were captured on a MiniMedical Automatic Film Processor (Imageworks). Image data was analyzed by ImageJ software.

\section{Statistic Analysis}

Statistical analysis was performed on all data using student's unpaired t-test (two-tailed). A statistically significant difference was considered with a $p$ value less than 0.05 .

\section{Results}

8-HOA inhibits breast cancer cell growth and migration Treatment of 8 -HOA $(1.0 \mu \mathrm{M}, 48 \mathrm{~h})$ significantly suppressed the colony formation of MDA-MB 231 cells in a reduced surviving fraction of $75.5 \pm 6.2 \%$ vs. $100 \%$ in control (no 8-HOA treatment, Fig. 1a, $p<0$. 05). 8-HOA treatment $(1.0 \mu \mathrm{M}, 48 \mathrm{~h})$ also greatly suppressed the colony formation of 4 T1 cells (surviving fraction of $80.5 \pm 3.6$ vs. $100 \%$ in control, $p<0.05)$.

Direct treatment of 8-HOA can also significantly inhibit cancer cell migration. Using the wound healing assay, MDA-MB 231 cells exhibited $72.8 \%$ of the original wound areas upon 8-HOA treatment $48 \mathrm{~h}$ vs. $50.1 \%$ in control (no 8-HOA treatment, Fig. 1b, $p<0.05)$. Similarly, suppressed migration of 4 T1 cells was also observed upon 8 -HOA treatment with a wound area at $48 \mathrm{~h} 42.9 \%$ vs. $26.9 \%$ in control (Fig. 1c, $p<0.05$ ).
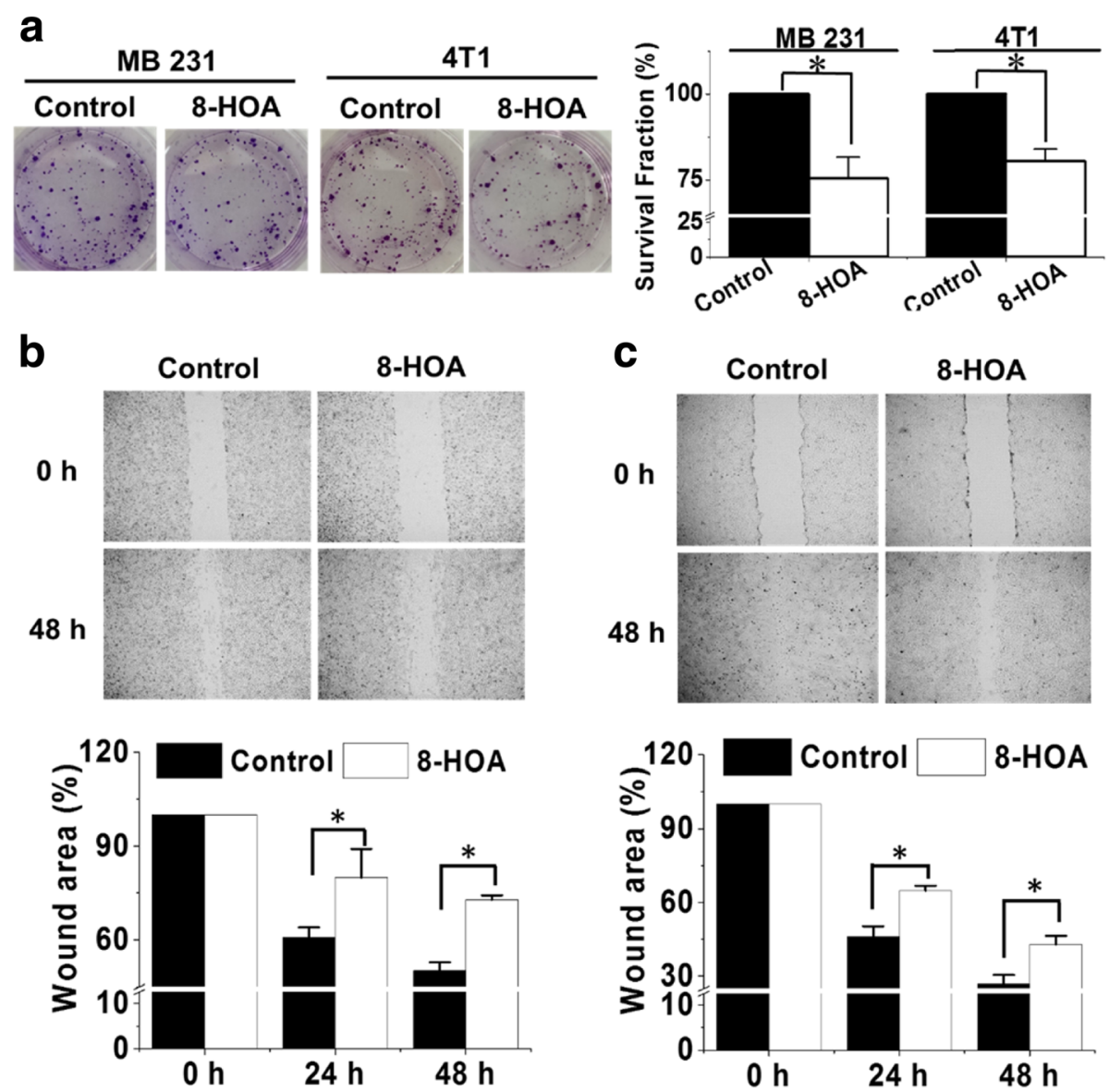

Fig. 1 8-HOA inhibits breast cancer cell growth and migration. a Colony formation of MDA-MB 231 and 4 T1 cells at 10 days after 8-HOA treatment $(1.0 \mu \mathrm{M}$ for $48 \mathrm{~h})$ and quantification analysis; $\mathbf{b}$ Wound healing assay and quantification of MDA-MB-231 cells upon 8-HOA treatment $(1.0 \mu \mathrm{M})$ for $48 \mathrm{~h}$. The MDA-MB 231 cells treated with vehicle were used as control; and $\mathbf{c}$ Wound healing assay and quantification of $4 \mathrm{~T} 1 \mathrm{cells}$ upon 8-HOA treatment $(1.0 \mu \mathrm{M})$ for $48 \mathrm{~h}$. The $4 \mathrm{~T} 1$ cells treated with vehicle were used as control. Data represent as mean \pm standard deviation (*: significant difference with $p<0.05$ from $n \geq 3$ ) 


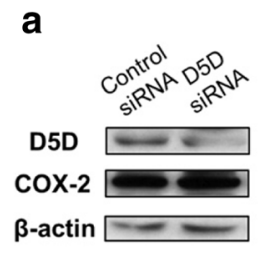

b

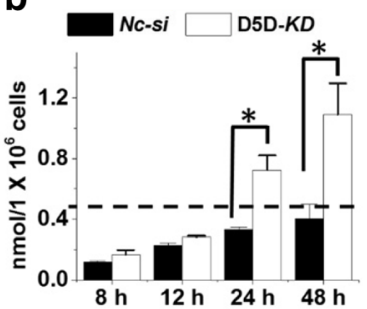

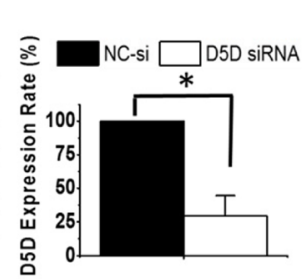

d
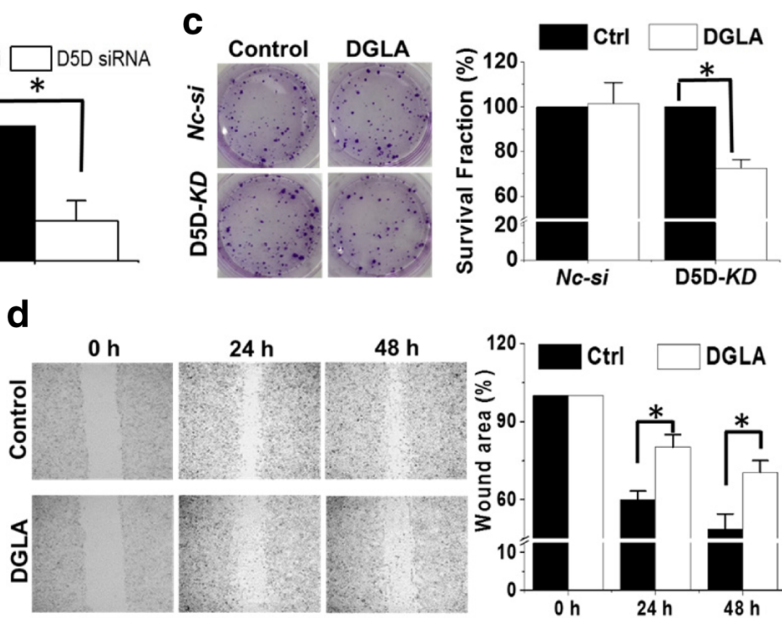

$24 \mathrm{~h}$
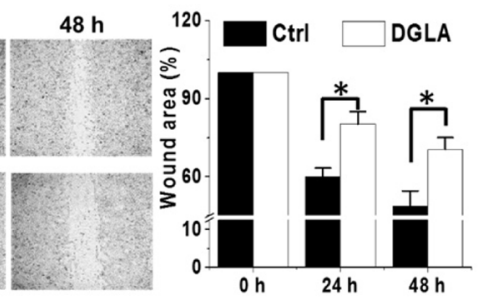

Fig. 2 D5D-KD and DGLA inhibit MDA-MB 231 cell growth and migration. a Western blot and protein expression rate of D5D and COX-2 in MDAMB 231cells after D5D siRNA transfection ( $\beta$-actin as loading control). Similar inhibition of D5D ( 70\%) was also observed in shRNA transfected MDA-MB-231 cells; b GC/MS quantification of 8-HOA from cell medium containing $1.0 \times 10^{6}$ siRNA D5D-KD MDA-MB 231 cells or control siRNA transfected cells after $100 \mu \mathrm{M}$ DGLA treatment. Similar results were also observed in shRNA transfected cell lines vs. their controls (data not shown); c Colony formation of D5D-KD MDA-MB231 or control siRNA transfected cells 10 days after DGLA treatment (100 $\mu M$ for 48 h); and $\mathbf{d}$ Wound healing assays and quantification of wound area of D5D-KD MDA-MB 231 cells upon DGLA (100 $\mu$ M, 48 h) treatment vs. controls (without DGLA). Data represent as mean \pm standard deviation (*: significant difference with $p<0.05$ from $n \geq 3$ )

\section{D5D-KD promoted 8-HOA formation to inhibit breast}

\section{cancer cell growth and migration}

When MDA-MB 231 cells were transfected with D5Dtargeted siRNA and treated with $100 \mu \mathrm{M}$ DGLA, endogenous 8-HOA accumulated and reached a threshold and physiological level $\geq 0.5 \mu \mathrm{M}\left(\mathrm{nmol} / 1 \times 10^{6}\right.$ cells $\left./ \mathrm{mL}\right)$ [47-49] at $24 \mathrm{~h}$ and $48 \mathrm{~h}$ (Fig. 2a and b). By comparison, in negative control siRNA transfected cells (Nc-si) treated with DGLA, the 8-HOA formation never reach $0.5 \mu \mathrm{M}$ threshold level during $48 \mathrm{~h}$ incubation (Fig. 2b). In addition, when COX-2 was knocked down in cancer cells, only trace level of 8-HOA was detected (Additional file 1: Figure S1), indicating the formation of 8-HOA is COX-2 dependent. In D5D-KD MDA-MB 231

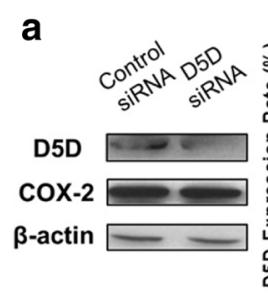

b

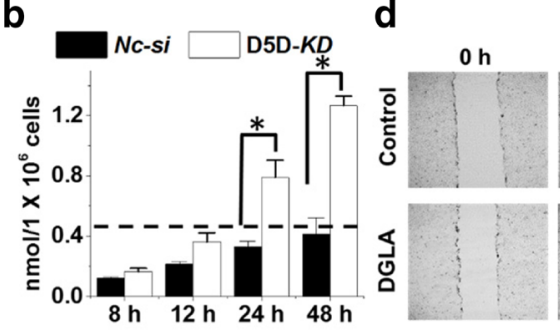

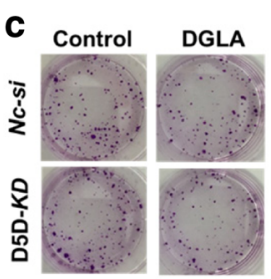
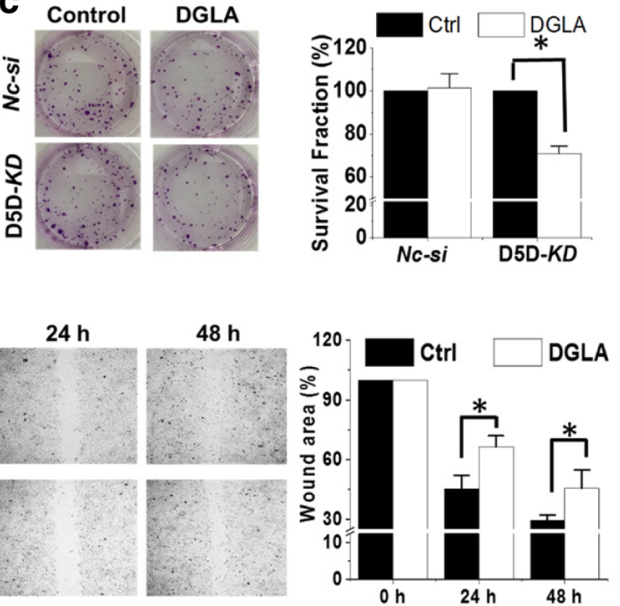

Fig. 3 D5D-KD and DGLA inhibit 4 T1 cells growth and migration. a Western blot and protein expression rate of D5D and COX-2 in 4 T1 cells after D5D siRNA transfection ( $\beta$-actin as loading control). Similar inhibition of D5D was also observed in shRNA transfected 4 T1 cells; b GC/MS quantification of 8-HOA from cell medium containing $1.0 \times 10^{6}$ D5D-KD 4 T1 cells or control siRNA transfected cells after $100 \mu M$ DGLA treatment, Similar results were also observed in shRNA transfected cell lines vs. their controls (data not shown); c Colony formation of D5D-KD 4 T1 or control siRNA transfected cells at 10 days after DGLA treatment (100 $\mu \mathrm{M}$ for $48 \mathrm{~h}$ ); and $\mathbf{d}$ Wound healing assays and quantification of wound area of D5D-KD 4 T1 cells upon DGLA $(100 \mu \mathrm{M}, 48 \mathrm{~h})$ treatment vs. controls (without DGLA). Data represent as mean \pm standard deviation (*: significant difference with $p<0.05$ from $n \geq 3$ ) 

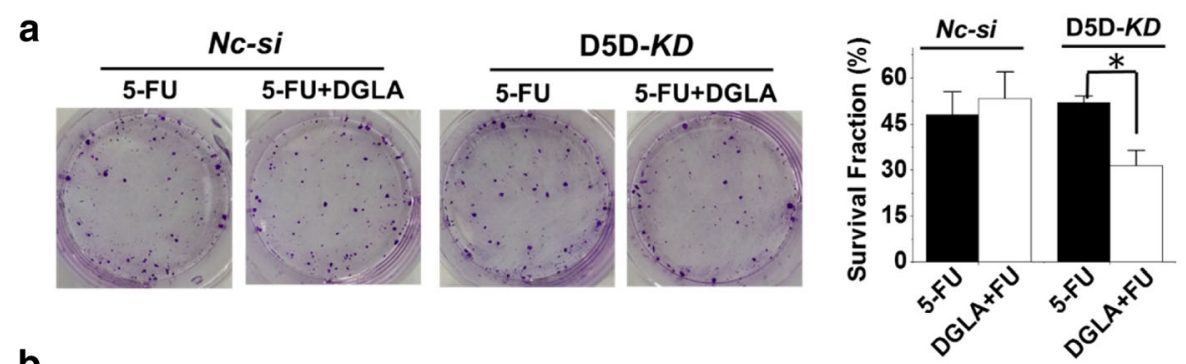

b
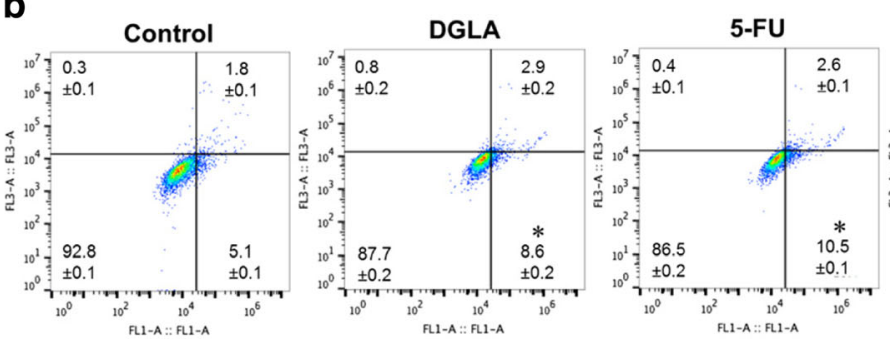

5-FU + DGLA

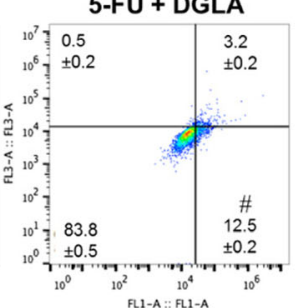

Fig. 4 D5D-KD and DGLA supplementation enhance the efficacy of 5-FU on growth of MDA-MB 231 cells. a Colony formation assay of D5D-KD

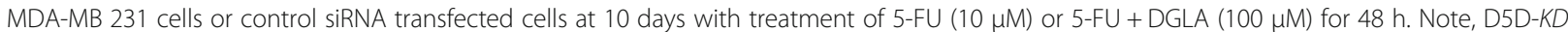
and NC-si control cells without DGLA and 5-FU treatment (shown in Fig. 2) were used to calculate survival fractions; and $\mathbf{b}$ Cell apoptosis was

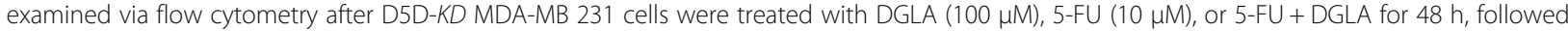
by Annexin V-FITC/PI double staining. Data represent as mean \pm standard deviation (*: significant difference vs. control with $p<0.05$; \#: significant difference vs. 5-FU group with $p<0.05$ from $n \geq 3$ )

cells, with the promoted 8-HOA formation, DGLA supplementation $(100 \mu \mathrm{M})$ significantly suppressed cancer cell growth with surviving fraction of $\sim 72.5 \pm 3.9 \%$ vs. $100 \%$ in control (no DGLA, Fig. 2c, $p<0.05$ ). In contrast, in control NC-si cells, DGLA supplementation could not inhibit cancer cell growth since 8-HOA formation never reached the threshold level due to the putative conversion of DGLA to the downstream fatty acid AA. These observations suggested that D5D-KD can promote 8-HOA formation from COX-catalyzed DGLA peroxidation, thus inhibiting the growth of human breast cancer cells that overexpress COX-2. a

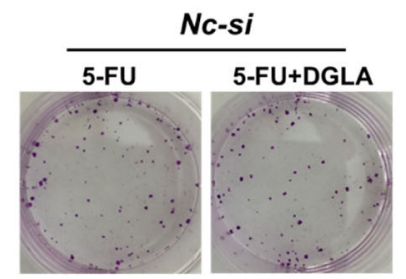

b

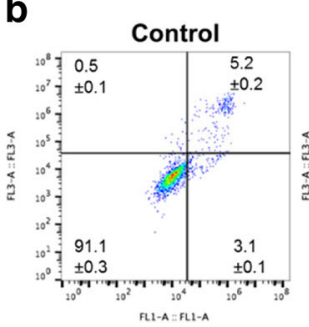

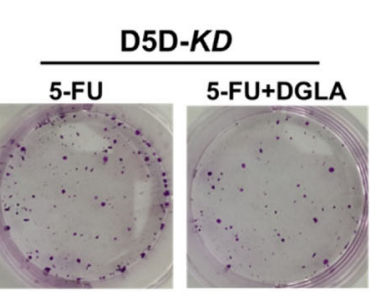
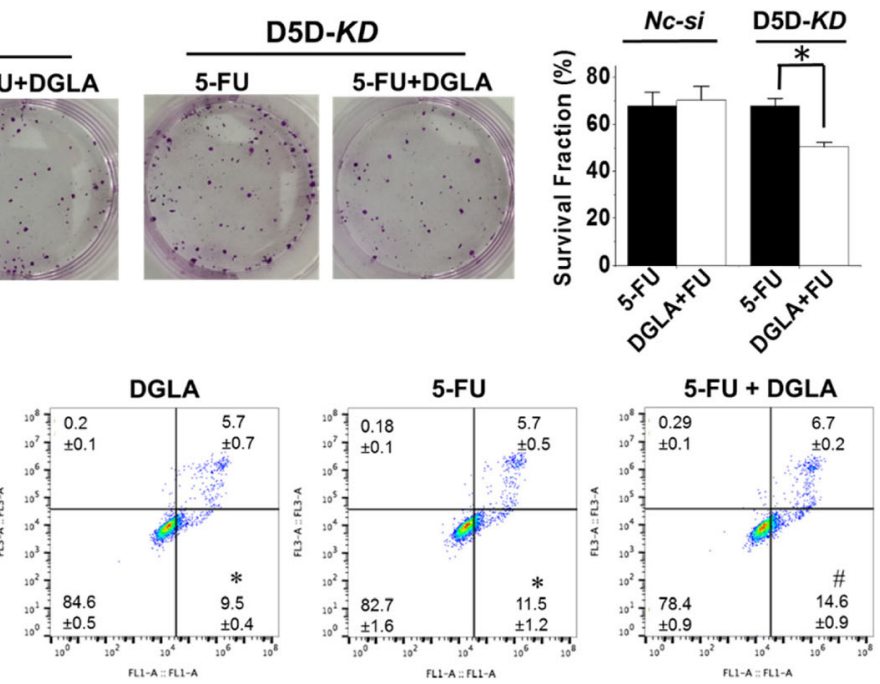

Fig. 5 D5D-KD and DGLA supplementation enhance the efficacy of 5-FU on growth of 4 T1 cells. a Colony formation assay of D5D-KD 4 T1 cells or control siRNA transfected cells at 10 days with treatment of 5-FU $(20 \mu \mathrm{M})$ or 5-FU + DGLA $(100 \mu \mathrm{M})$ for 48 h. Note, D5D-KD and NC-si control cells without DGLA and 5-FU treatment (shown in Fig. 3) were used to calculate survival fractions; and $\mathbf{b}$ Cell apoptosis was examined via flow cytometry after D5D-KD 4 T1 cells were treated with DGLA $(100 \mu \mathrm{M})$, 5-FU $(20 \mu \mathrm{M})$, or 5-FU + DGLA for 48 h, followed by Annexin V-FITC/PI double staining Data represent as mean \pm standard deviation (*: significant difference vs. control with $p<0.05$; and \#: significant difference vs. 5-FU group with $p<0.05$ from $n \geq 3$ ) 
When $4 \mathrm{~T} 1$ cells were transfected with D5D-targeted siRNA and treated with $100 \mu \mathrm{M}$ DGLA, 8-HOA also accumulated and reached a threshold level of $\geq 0.5 \mu \mathrm{M}$ [47-49] at $24 \mathrm{~h}$ and $48 \mathrm{~h}$ (Fig. 3a and b). However, the formation of 8 -HOA in negative control siRNA transfected cells never reach $0.5 \mu \mathrm{M}$ (Fig. 3b). DGLA supplementation $(100 \mu \mathrm{M})$ in D5D-KD 4 T1 cells also significantly suppressed cancer cell growth generating a surviving fraction of $70.8 \pm 3.6 \%$ vs. $100 \%$ in control (no DGLA treatment, Fig. 3c, $p<0.05$ ). Again in NC-si $4 \mathrm{~T} 1$ cells, DGLA supplementation did not inhibit cancer cell growth, confirming that the growth inhibitory effect of DGLA is derived from increased 8-HOA from the D5D$K D$ strategy.

Endogenous 8-HOA in D5D-KD cells (via shRNA transfection) after DGLA supplementation can also greatly inhibit cancer cell migration. There was significantly suppressed migration in D5D-KD MDA-MB 231 cells upon DGLA treatment $48 \mathrm{~h}$ with a wound area of $70.5 \%$ vs. $48.8 \%$ in control (Fig. 2 d, $p<0.05$ ), and inhibited migration of D5D-KD 4 T1 cells upon DGLA treatment $48 \mathrm{~h}$ with a wound area of $45.5 \%$ vs. $29.6 \%$ in control (Fig. $3 \mathrm{~d}, p<0.05$ ). Note, no differences in wound areas were observed upon $48 \mathrm{~h}$ DGLA treatment for either NC-sh MDA-MB 231 or NC-sh 4 T1 cell lines (Additional file 2: Figure S2).

D5D-KD (siRNA transfection) enhances the efficacy of 5-FU on breast cancer cell growth

Co-treatment of DGLA $(100 \mu \mathrm{M})$ and 5-FU $(10 \mu \mathrm{M})$ in D5D-KD MDA-MB 231 cells enhanced cell growth inhibition, and resuted in a surviving fraction $31.5 \pm 5$. $1 \%$ vs. $52.1 \% \pm 2.0 \%$ in 5 -FU treatment alone (Fig. $4 \mathrm{a}$ ), while in $N C$-si cells, the co-treatment did not lead to any improvement compared to 5-FU treament alone. Concurrent DGLA treatment $(100 \mu \mathrm{M})$ also promoted 5-FU-induced apoptosis in D5D-KD MDA-MB 231 cells. Flow cytometric analysis revealed an increased early apoptotic cell population of $12.5 \% \pm 0.2 \%$
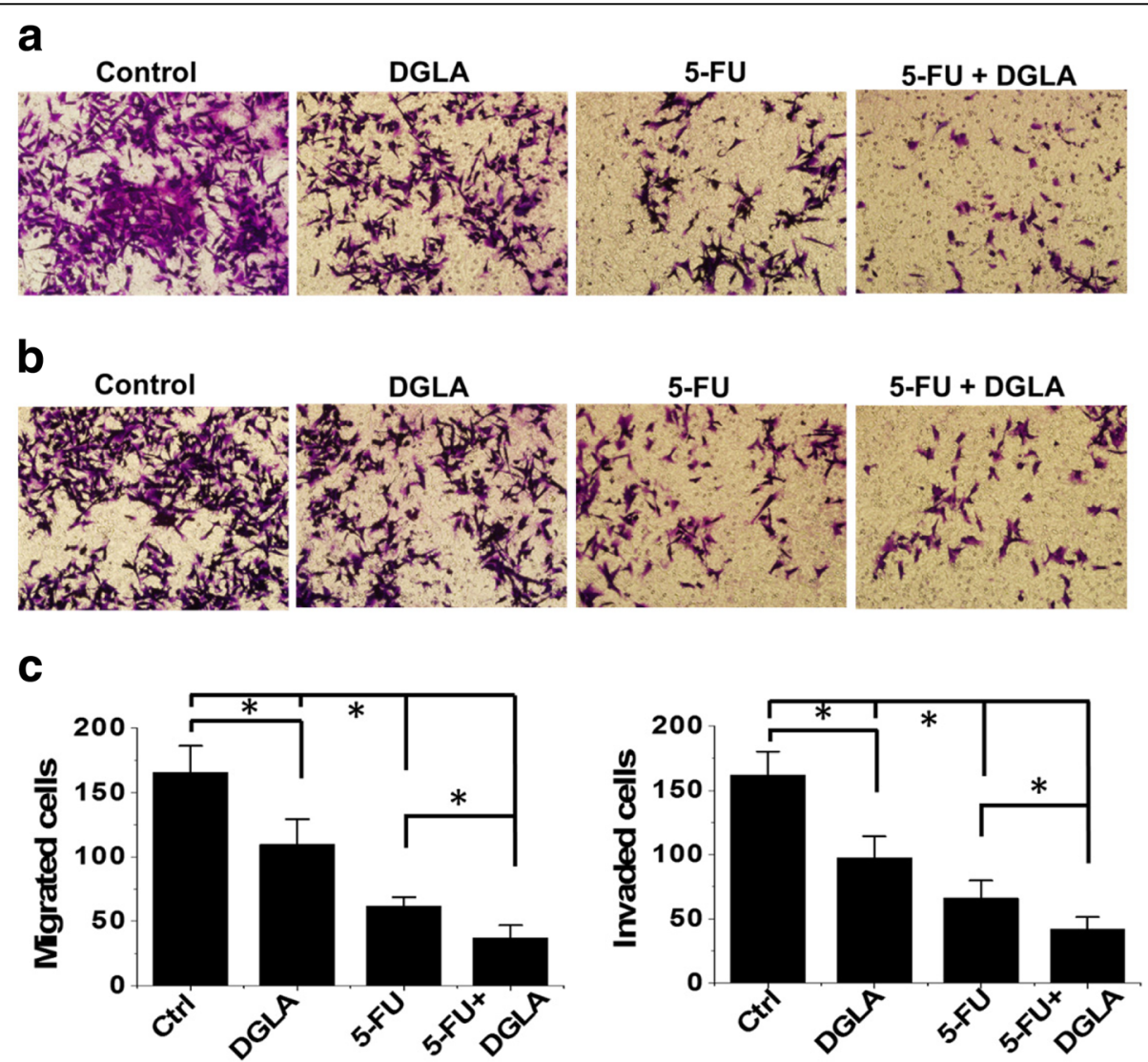

Fig. 6 Efficacy of 5-FU on cell migration and invasion in MDA-MB 231 cells was enhanced by D5D-KD (via shRNA) and DGLA treatment. a Transwell

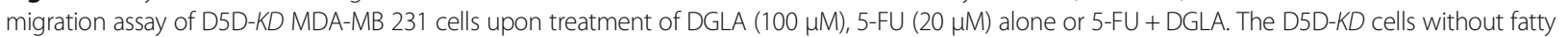
acid and drug treatment were used as controls; b Transwell invasion assay of D5D-KD MDA-MB 231 cells upon treatment of DGLA (100 $\mu M$ ), 5-FU $(20 \mu \mathrm{M})$ alone or 5-FU + DGLA. The D5D-KD cells without fatty acid and drug treatment were used as controls; and c Quantification of transwell migration and invasion assay of D5D-KD MDA-MB 231 cells. Data represent as mean \pm standard deviation (*: significant difference with $p<0.05$ from $n \geq 3$ ) 
(annexin $\mathrm{V}^{+} / \mathrm{PI}^{-}$staining) compared to that in $5-\mathrm{FU}$ only group $(10.5 \% \pm 0.1 \%$, Fig. $4 b)$.

D5D-KD along with DGLA supplementation also enhanced the efficacy of 5-FU on the growth inhibition of 4 T1 cells. For example, co-treatment of DGLA $(100 \mu \mathrm{M})$ and 5-FU $(20 \mu \mathrm{M})$ in D5D-KD 4 T1 cells enhanced cell growth inhibition with a surviving fraction $50.3 \pm 1.9 \%$ vs. $67.7 \% \pm 3.4 \%$ in 5 -FU treatment alone (Fig. 5a), while in $\mathrm{NC}$-si cells the co-treatment did not improve the growth inhibition effect compared to 5-FU treament alone. DGLA supplementation also promoted 5-FU-induced apoptosis of D5D-KD 4 T1 cells (early apoptotic cell population of $14.6 \% \pm 0.9 \%$, Fig. 5 b) vs. 5 FU alone (11.5\% $\pm 1.2 \%$, Fig. $5 b)$.

\section{D5D-KD (shRNA transfection) enhances the efficacy of} 5-FU on breast cancer cell migration

DGLA treatment also enhanced the inhibition effects of 5 -FU on the migration of D5D-KD MDA-MB 231 cells. Upon co-treatment of DGLA and 5-FU there were approximately $40 \%$ less cells that migrated compared to treatment with 5-FU alone (37 cells migrated after cotreatment of DGLA and 5-FU vs. 62 cells after 5-FU treatment, Fig. 6a). Invasion by D5D-KD MDA-MB 231 cells was also further inhibited by the co-treatment of DGLA and 5-FU. The number of cells that accomplished invasion upon co-treatment of DGLA and 5-FU was $36 \%$ less than treatment with 5 -FU alone (number of cells that invaded was 42 for co-treatment vs. 66 for 5FU, Fig. 6b and c).

D5D-KD and DGLA treatment also improved the efficacy of 5-FU on the migration of $4 \mathrm{~T} 1$ cells. The number of migrated cells upon co-treatment with DGLA and 5FU was $41 \%$ less when compared to treatment with 5-FU alone (30 cells migrated after co-treatment with DGLA and 5-FU vs. 51 cells after 5-FU only, Fig. 7a). The transwell invasion assays showed that co-treatment of DGLA with 5-FU further inhibited cell invasion compared to 5FU alone in D5D-KD 4 T1 cells. The number of cells that invaded upon co-treatment with DGLA and 5-FU was $34 \%$ less than treatment with 5-FU (33 cells invaded after co-treatment vs. $\sim 50$ cells after 5 -FU alone, Fig. $7 \mathrm{~b}$ and c).
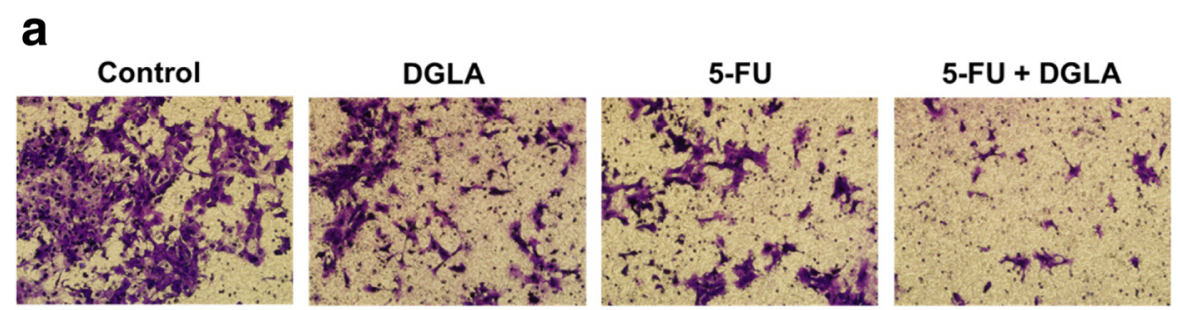

\section{b}
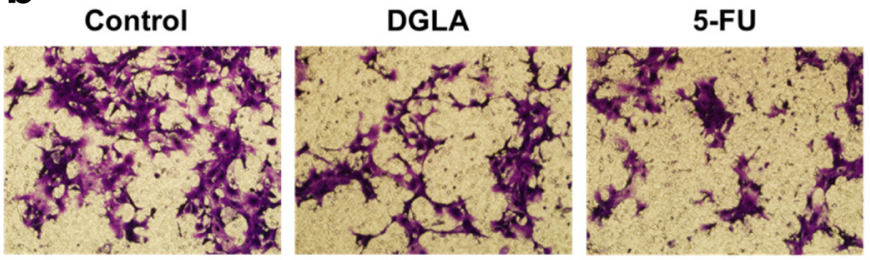

5-FU + DGLA

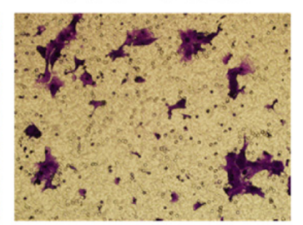

C
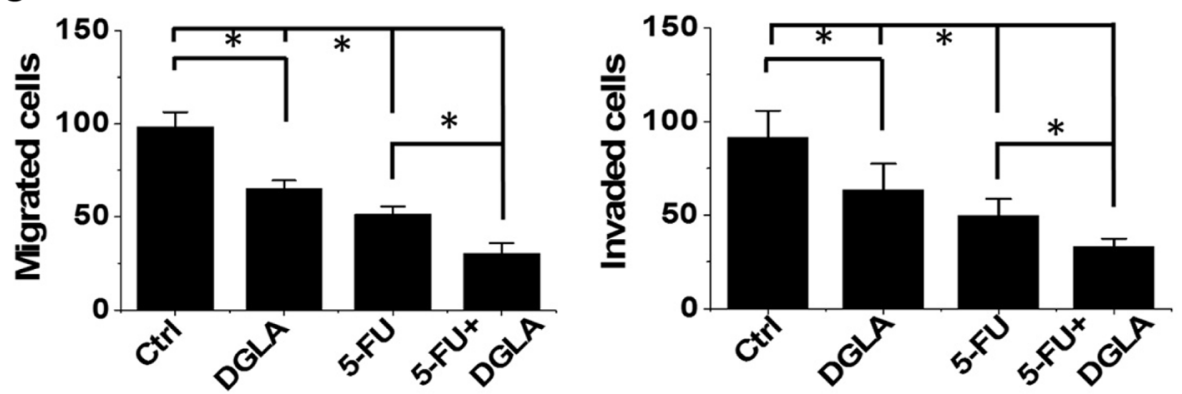

Fig. 7 Efficacy of 5-FU on cell migration and invasion in 4 T1 cells was enhanced by D5D-KD (via shRNA) and DGLA treatment. a Transwell migration assay of D5D-KD 4 T1 cells upon treatment of DGLA $(100 \mu \mathrm{M}), 5-F U(50 \mu \mathrm{M})$ alone or 5-FU + DGLA. The D5D-KD cells without fatty acid and drug treatment were used as controls; $\mathbf{b}$ Transwell invasion assay of D5D-KD 4 T1 cells upon treatment of DGLA (100 $\mu \mathrm{M}), 5-\mathrm{FU}(50 \mu \mathrm{M})$ alone or 5-FU + DGLA. The D5D-KD cells without fatty acid and drug treatment were used as controls; and c Quantification of transwell migration and invasion assay of D5D-KD 4 T1 cells. Data represent as mean \pm standard deviation (*: significant difference with $p<0.05$ from $n \geq 3$ ) 
Mechanism of anti-cancer effect from D5D-KD, DGLA along with 5-FU in cancer cells

Consistent with the results demonstrated in colon and pancreatic cancer cells [46-49], both direct 8-HOA treatment and endogenous 8-HOA resulting from D5D$K D$ and DGLA treatment in MDA-MB 231 cells upregulated AcH3 (substrate of histone deacetylase or HDAC) and $\gamma \mathrm{H}_{2} \mathrm{AX}$ (DNA damage marker, Fig. 8a), indicating that 8-HOA can suppress cancer cell growth by inhibiting HDAC and inducing DNA damage.

5-FU inhibited cancer cell growth by inducing DNA damage and cell apoptosis, which was evident by activation of procaspase 9 , cleavage of PARP and an increase in the DNA damage marker $\gamma \mathrm{H}_{2} \mathrm{AX}$ (Fig. 8a), consistent with other reports [51,52]. When the cells were co-treated with DGLA $(100 \mu \mathrm{M})$ and 5-FU $(20 \mu \mathrm{M})$, procaspase 9 was more significantly reduced. An increased level of cleaved PARP as well as a slightly increased level of $\gamma \mathrm{H}_{2} \mathrm{AX}$ were observed compared to 5-FU treatment alone in D5D-KD MDA-MB 231 cells (Fig. 8a). Note, no change in AcH3 level was observed upon 5-FU treatment alone.
5-FU also inhibited cancer cell migration and invasion by downregulating the expression of MMP-9, mesenchymal marker vimentin and EMT-inducing transcription factor snail and simultaneously upregulating the expression of epithelial marker E-cadherin (Fig. 8b) [53-57]. Decreased expression of MMP-9, vimentin, snail and increased expression of E-cadherin were also observed when D5D-KD MDA-MB 231 cells were co-treated with DGLA and 5-FU.

We also tested the possible anti-cancer mechanisms of our strategy in D5D-KD 4 T1 cells. Promoted 8-HOA formation from D5D-KD and DGLA treatment in $4 . \mathrm{T} 1$ cells could upregulate AcH3 and $\gamma \mathrm{H} 2 \mathrm{AX}$ level (Fig. 9a). The co-treatment of DGLA and 5-FU in D5D-KD 4 T1 cells led to significantly less PARP compared to 5-FU treatment alone (Fig. 9a). Treatment with 5-FU alone also decreased expression of MMP-9, vimentin and snail as well as increased expression of E-cadherin in D5DKD $4 \mathrm{~T} 1$ cells (Fig. 9b). When co-treated with DGLA and 5-FU, further reduction in expressions of MMP-9, vimentin and snail as well as increased expression of E-
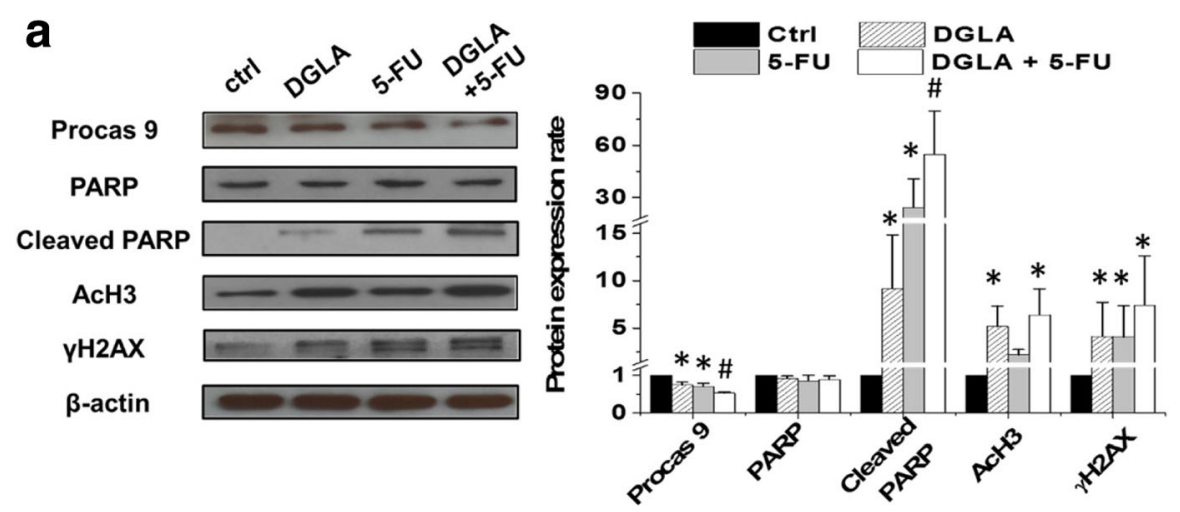

b

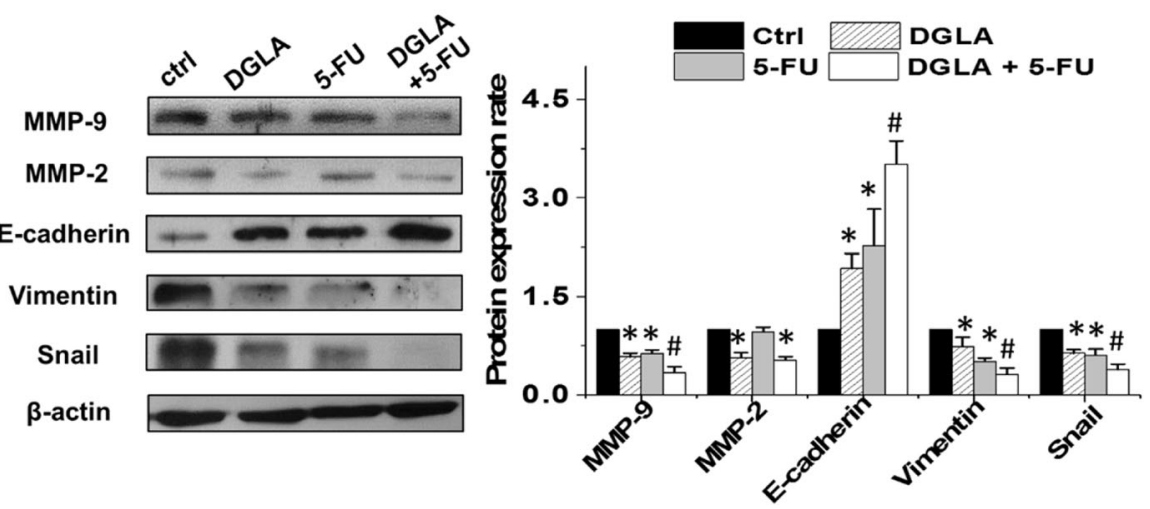

Fig. 8 Mechanism of anti-cancer effect from D5D knockdown, DGLA supplementation along with 5-FU in MDA-MB 231 cells. a Western blot of

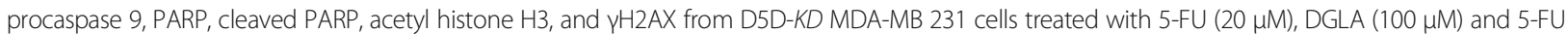
+ DGLA at $48 \mathrm{~h}$. Protein expression rate was normalized using $\beta$-actin as a loading control; and $\mathbf{b}$ Western blot of MMP-2, MMP-9, E-cadherin, vimentin and snail from D5D-KD MDA-MB 231 cells treated with 5-FU (20 $\mu \mathrm{M})$, DGLA (100 $\mu \mathrm{M})$ and 5-FU + DGLA at 48 h. Protein expression rate was normalized using $\beta$-actin as a loading control. Data represent as mean \pm standard deviation (*: significant difference vs. control with $p<0.05$; and \#: significant difference vs. 5-FU group with $p<0.05$ from $n \geq 3$ ) 

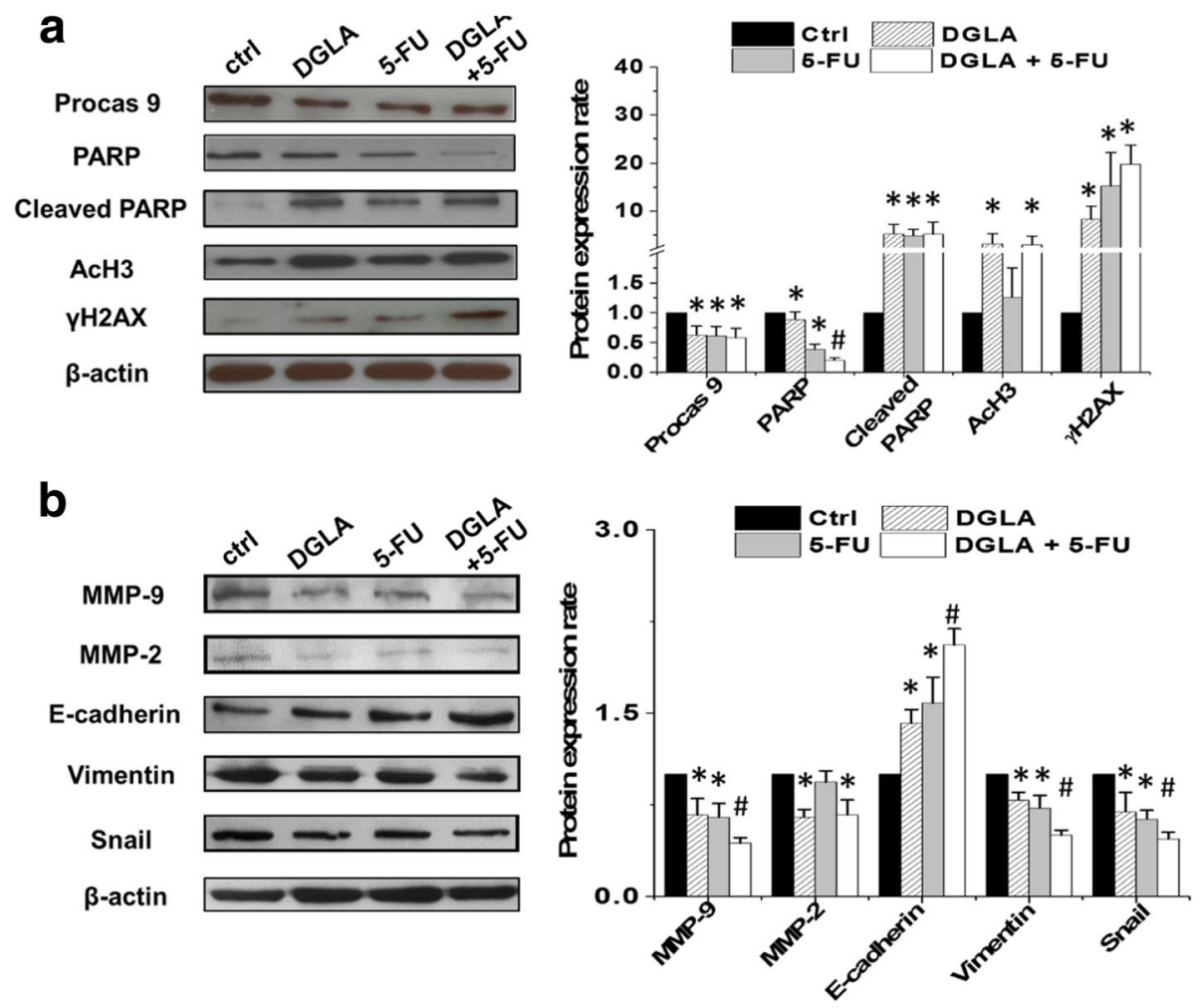

Fig. 9 Mechanism of anti-cancer effect from D5D knockdown, DGLA supplementation along with 5-FU in 4 T1 cells. a Western blot of procaspase

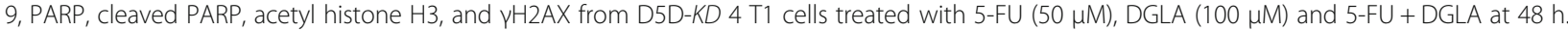
Protein expression rate was normalized using $\beta$-actin as a loading control; and $\mathbf{b}$ Western blot of MMP-2, MMP-9, E-cadherin, vimentin and snail from D5D-KD 4 T1 cells treated with 5-FU $(50 \mu \mathrm{M})$, DGLA (100 $\mu \mathrm{M})$ and 5-FU + DGLA at 48 h. Protein expression rate was normalized using $\beta$-actin as a loading control. Data represent as mean \pm standard deviation (*: significant difference vs. control with $p<0.05$; and \#: significant difference vs. 5-FU group with $p<0.05$ from $n \geq 3$ )

cadherin were observed in D5D-KD 4 T1 cells compared to the cells with 5-FU treatment alone.

\section{Discussion}

Our previous work demonstrated that the distinct byproduct 8-HOA could be generated from COX-catalyzed peroxidation of DGLA. Further studies showed that 8-HOA can inhibit colon and pancreatic cancer cell growth and metastasis, via inhibiting HDAC and inducing DNA damage [46-49]. We thus proposed that the commonly high COX expression in cancer cells can be taken advantage by inhibiting D5D to promote 8-HOA formation and thus DGLA's anti-cancer activity. Unlike the classic COX-2 inhibition strategy in cancer treatment where overexpressed COX-2 is the problem, high COX-2 in our new strategy is no longer the problem but instead a benefit to kill cancer cells. Here we demonstrated that D5D knockdown can enhance COX-2 mediated DGLA peroxidation and then promote 8 -HOA formation to a threshold level $(\geq 0.5 \mu \mathrm{M})$ , thereby leading to the inhibition of growth and migration in breast cancer cells. Our strategy also greatly enhanced the efficacies of a chemotherapeutic drug (5-FU) in breast cancer.
We observed that direct treatment of $8-\mathrm{HOA}$ at 1 . $0 \mu \mathrm{M}$ significantly suppressed the colony formation and migration of MDA-MB 231 and 4 T1 cells (Fig. 1). Here we tested the $8-\mathrm{HOA}$ at $1.0 \mu \mathrm{M}$ because this is the physiologically relevant concentration of 8 -HOA that was detected in our experiment (Figs. 2 and 3). Note, the inhibitory effects from 8-HOA observed in our experiments were only from a single dose treatment. We have recently finished an animal experiments in which we observed that 4-week supplement of DGLA to mice bearing xenograft tumors led to continuous generation and accumulation of 8-HOA, resulting in significant inhibition of tumor growth.

We proposed and demonstrated that there is a threshold level of 8-HOA that is required for eliciting DGLA's anti-cancer effects [46-49]. For example, $100 \mu \mathrm{M}$ of DGLA treatment in D5D-KD MDA-MB 231 and $D 5 D$ $K D 4 . \mathrm{T} 1$ cells resulted in endogenous $8-\mathrm{HOA} \geq 0.5 \mu \mathrm{M}$ in both of cell lines most time points for $48 \mathrm{~h}$ DGLA treatment, which then inhibited their colony formation (Figs. 2-3). In comparison, in both NC-si MDA-MB-231 and $N C$-si 4 T1 cells, endogenous 8-HOA never reached $0.5 \mu \mathrm{M}$ during $48 \mathrm{~h}$ DGLA treatment (Figs. 2-3), and is 
unable to be continually accumulated due to limited free DGLA at $48 \mathrm{~h}$ (Additional file 3: Table S1). Therefore no growth inhibitory effect was observed in both of the $\mathrm{NC}$ si cells. These observations together suggested that a threshold level of endogenous 8-HOA between 0.5-1. $0 \mu \mathrm{M}$ is required for eliciting anti-cancer activities.

We observed that D5D-KD and DGLA supplement promoted formation of 8-HOA which inhibits HDAC, evidence by detected higher level of acetyl histone $\mathrm{H} 3$, a substrate of HDAC (Figs. 8-9). Consistently, HDAC activity assay also showed that about $40 \%-50 \%$ of HDAC activity was inhibited in $4 \mathrm{~T} 1$ and MDA-MB-231 cells upon either direct treatment of 8-HOA or promoted 8HOA formation from D5D-KD along with $100 \mu \mathrm{M}$ DGLA treatment (Additional file 4: Figure S3). As HDAC catalyzes histone deacetylation, an important regulatory mechanism for DNA expression, inhibition of HDAC can induce DNA damage and inhibit cancer cell growth and migration. Our study demonstrated that D5D-KD along with DGLA treatment can promote formation of 8-HOA which serves as an HDACi to induce DNA damage, and consequently inhibit cancer cell growth and migration, via regulating key signaling proteins, e.g., MMPs-2, 9, e-cadherin, etc, Fig. 10).

5 -FU is one of the most commonly used first-line chemo-drug for many types of cancer, including breast cancer [58]. It acts as a thymidylate synthase inhibitor and interferes with DNA synthesis to inhibit cancer cell growth [59-62]. However, many breast cancer cells/tumors are resistant to 5-FU which is a major obstacle for successful cancer chemotherapy [1, 5, 63, 64]. Our study demonstrated that the D5D-KD and DGLA supplementation strategy could effectively enhance the efficacy of 5-FU on suppressing cancer growth, migration and invasion [46-49], due to their distinct mechanism to induce apoptosis and DNA damage. Thus, the combined approaches show great potential to be used as a complementary therapy to improve efficacies of many chemo-drugs.

In this study, besides a commonly used human breast cancer cell line MDA-MB 231, we also tested a mouse breast cancer cell line $4 \mathrm{~T} 1$ which is an excellent cell line for creating a breast tumor xenograft model in cancer research due to its high potential for growth and metastasis $[65,66]$. We have already established a mouse xenograft tumor model using $4 \mathrm{~T} 1$ cells for metastasis study [66], which will be continually used in our research to investigate the effect of our strategy on breast cancer growth and metastasis.

Delivery of therapeutic siRNA in cancer therapy has always been challenging. To overcome this problem, RNA nanoparticles have emerged recently as a new platform for in vivo delivery of siRNA and miRNA [67-69]. We are now working to develop thermodynamically and chemically stable RNA nanoparticles harboring D5D

\section{Prostaglandins-2}

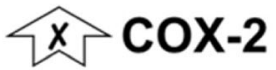

Arachidonic Acid (downstream $\omega-6$ )

shRNA 2 D5D

Dihomo-y-Linolenic Acid (DGLA)

$\checkmark$ COX-2

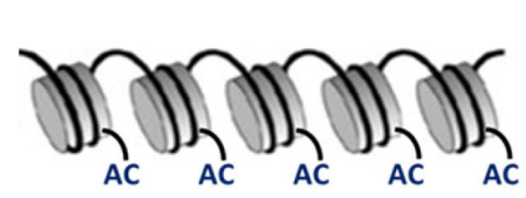

8-HOA (HDACi)
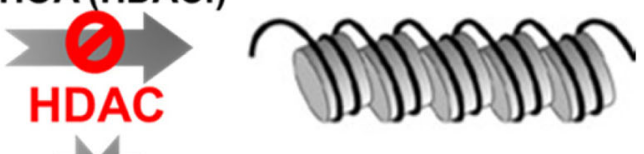

Altered Gene Transcription (Procaspase 9, PARP,

MMP-2, MMP-9, vimentin, snail, E-cadherin and etc.)

Biological Outcome for Cancer Cells:

Activation of Apoptosis and Inhibition of Metastasis

Fig. 10 Our proposed novel strategy to inhibit breast cancer growth, migration and invasion 
siRNA and a cancer targeting ligand for specific delivery of D5D siRNA to cancer cells and tumors. These novel RNA nanoparticles can specifically target cancer with little to no accumulation in healthy tissues, highlighting the benefits of translating RNA nanoparticles for cancer therapy with enhanced targeting efficiency and reduced side effects [67-69].

We have demonstrated that 8-HOA could directly inhibit the growth of cancer cells, not only in cancer cell lines overexpressing COX-2, but also in COX-2 deficient cancer cell lines $[46,47]$. Taking into account the fact that many types of tumors commonly overexpress COX2 , we propose that our strategy can also kill low or deficient COX-2 cancer cells in a paracrine-like manner as they surrounded by many other cancer cells (overexpressing COX-2) that produce enough 8-HOA. In addition, our new concept is also supported by a recent study from Dr. Bissonnette's lab in which COX-2 expression can be induced in a xenograft tumor model (HCT 116, COX-2 deficient colon cancer cell line), particularly in stroma [70].

\section{Conclusions}

In conclusion, the data presented in this study and our previous studies have demonstrated that D5D knockdown is an effective strategy to promote 8-HOA formation from COX-catalyzed DGLA peroxidation, which serves as a HDAC inhibitor to induce DNA damage, activate cell apoptosis and inhibits cancer cell growth and migration. Compared to the classic COX inhibition strategy in cancer treatment, our novel strategy will result in dual inhibitory effects on cancer, which not only limits deleterious PGE2 formation from arachidonic acid (the common objective of COX-2 inhibitor), but also promotes formation of 8 -HOA via capitalizing on high COX-2 expression in cancer as well as the abundance of $\omega-6 \mathrm{~s}$ in the daily diet. Thus, our strategy will lead to a better therapeutic outcome with less side effects to treat cancers, including breast cancer.

\section{Additional files}

Additional file 1: Figure S1. GC/MS quantification of 8-HOA from NC-si, D5D-KD and D5D/COX-2 double-KD MDA-MB 231/4 T1 cells after DGLA treatment. (DOCX $71 \mathrm{~kb})$

Additional file 2: Figure S2. Wound healing assays of NC-sh MDA-MB231 and NC-sh 4 T1 cells upon DGLA treatment vs. controls. (DOCX 827 kb)

Additional file 3: Table S1. LC/MS quantification of DGLA and AA from Nc-si MB 231, D5D-KD MB 231, Nc-si 4 T1 or D5D-KD 4 T1 cells after DGLA treatment. (DOCX $17 \mathrm{~kb}$ )

Additional file 4: Figure S3. HDAC activity assay of D5D-KD $4 \mathrm{~T} 1$ and D5D-KD MDA-MB-231 cells treated with vehicle or DGLA. (DOCX $36 \mathrm{~kb}$ )

\section{Abbreviations}

5-FU: 5-flurouracil; 8-HOA: 8-hydroxyoctanoic acid; AA: Arachidonic acid; COX: Cyclooxygenase; D5D: Delta-5-desaturase; D5D-KD: Delta-5-desaturase knockdown; DGLA: Dihomo-y-linolenic acid; HDAC: Histone deacetylase; HDACi: Histone deacetylase inhibitor; NC-sh: Negative control shRNA transfected; NC-si: Negative control siRNA transfected

\section{Acknowledgements}

We would like to thank Dr. Jodie Haring for her help on editing the manuscript.

\section{Funding}

This work was supported by National Cancer Institute (R15CA195499), National Institute of General Medical Sciences (P20GM109024), and Sanford Health-NDSU Seed Grant (FAR0026507). The funding bodies have no role in the design of the study and collection, analysis, and interpretation of data and in writing the manuscript.

\section{Availability of data and materials}

The datasets used and/or analysed during the current study are available from the corresponding author on reasonable request.

\section{Authors' contributions}

SYQ made substantial contributions to provide funding support, conception design, interpretation of data, and write/edit manuscript. KM, YYH, and LY all made substantial contributions to conception and design, and interpretation of data. YX, XY and TW made substantial contributions to acquisition of data, or analysis and interpretation of data. All authors have read and approved the final manuscript.

Ethics approval and consent to participate

No ethics approval and informed consent are needed for this study.

Consent for publication

Not applicable

\section{Competing interests}

The authors declare that they have no competing interest.

\section{Publisher's Note}

Springer Nature remains neutral with regard to jurisdictional claims in published maps and institutional affiliations.

\section{Author details}

'Department of Pharmaceutical Sciences, North Dakota State University, Fargo, ND 58108, USA. ²Department of Transplantation, Mayo Clinic Florida, Jacksonville, FL 32224, USA. ${ }^{3}$ Department of Medicine, Section of Dermatology, University of Chicago, Chicago, USA. ${ }^{4}$ Cancer Biology Research Center, Sanford Research, Sioux Falls, SD 57104, USA.

Received: 16 June 2017 Accepted: 19 March 2018

Published online: 27 March 2018

References

1. Tecza K, Pamula-Pilat J, Lanuszewska J, Grzybowska E. Genetic polymorphisms and response to 5 -fluorouracil, doxorubicin and cyclophosphamide chemotherapy in breast cancer patients. Oncotarget. 2016;7:66790-808.

2. Zhang J, Zhang Z, Wang Q, Xing XJ, Zhao Y. Overexpression of microRNA365 inhibits breast cancer cell growth and chemo-resistance through GALNT4. Eur Rev Med Pharmacol Sci. 2016;20:4710-8.

3. Chen L, Jin T, Zhu K, Piao Y, Quan T, Quan C, Lin Z. PI3K/mTOR dual inhibitor BEZ235 and histone deacetylase inhibitor Trichostatin A synergistically exert anti-tumor activity in breast cancer. Oncotarget. 2017; Epub ahead of print

4. Pusztai L, Karn T, Safonov A, Abu-Khalaf MM, Bianchini G. New Strategies in Breast Cancer: Immunotherapy. Clin Cancer Res. 2016;22:2105-10.

5. Sagara A, Igarashi K, Otsuka M, Karasawa T, Gotoh N, Narita M, Kuzumaki N, Narita M, Kato Y. Intrinsic Resistance to 5 -fluorouracil in a brain metastatic variant of human breast cancer cell line, MDA-MB-231BR. PLoS One. 2016; 11:e0164250.

6. Chamras H, Ardashian A, Heber D, Glaspy JA. Fatty acid modulation of MCF7 human breast cancer cell proliferation, apoptosis and differentiation. J Nutr Biochem. 2002;13:711-6. 
7. Serini S, Piccioni E, Merendino N, Calviello G. Dietary polyunsaturated fatty acids as inducers of apoptosis: implications for cancer. Apoptosis. 2009;14: 135-52

8. Spencer L, Mann C, Metcalfe M, Webb M, Pollard C, Spencer D, Berry D, Steward W, Dennison A. The effect of omega-3 FAs on tumour angiogenesis and their therapeutic potential. Eur J Cancer. 2009;45: 2077-86.

9. Horia E, Watkins BA. Complementary actions of docosahexaenoic acid and genistein on COX-2, PGE2 and invasiveness in MDA-MB-231 breast cancer cells. Carcinogenesis. 2007;28:809-15.

10. Volpato M, Perry SL, Marston G, Ingram N, Cockbain AJ, Burghel H, Mann J, Lowes D, Wilson E, Droop A, Randerson-Moor J, Coletta PL, Hull MA. Changes in plasma chemokine C-C motif ligand 2 levels during treatment with eicosapentaenoic acid predict outcome in patients undergoing surgery for colorectal cancer liver metastasis. Oncotarget. 2016;7:28139-50.

11. Vara-Messler M, Pasqualini ME, Comba A, Silva R, Buccellati C, Trenti A, Trevisi L, Eynard AR, Sala A, Bolego C, Valentich MA. Increased dietary levels of a-linoleic acid inhibit mammary tumor growth and metastasis. Eur J Nutr. 2015:56:509-19.

12. Nabavi SF, Bilotto S, Russo GL, Orhan IE, Habtemariam S, Daglia M, Devi KP, Loizzo MR, Tundis R, Nabavi SM. Omega-3 polyunsaturated fatty acids and cancer: lessons learned from clinical trials. Cancer Metastasis Rev. 2015;34: 359-80.

13. Thiebaut AC, Chajes V, Gerber M, Boutron-Ruault MC, Joulin V, Lenoir G, Berrino F, Riboli E, Bénichou J, Clavel-Chapelon F. Dietary intakes of omega6 and omega-3 polyunsaturated fatty acids and the risk of breast cancer. Int J Cancer. 2009;124:924-31.

14. Pot GK, Geelen A, van Heijningen EM, Siezen CL, van Kranen HJ, Kampman E. Opposing associations of serum n-3 and n-6 polyunsaturated fatty acids with colorectal adenoma risk: an endoscopy-based case-control study. Int J Cancer. 2008;123:1974-7.

15. Nandi P, Girish GV, Majumder M, Xin X, Tutunea-Fatan E, Lala PK. PGE2 promotes breast cancer-associated lymphangiogenesis by activation of EP4 receptor on lymphatic endothelial cells. BMC Cancer. 2017;17:11

16. Gan L, Qiu Z, Huang J, Li Y, Huang H, Xiang T, Wan J, Hui T, Lin Y, Li H, Ren G. Cyclooxygenase-2 in tumor-associated macrophages promotes metastatic potential of breast cancer cells through Akt pathway. Int J Biol Sci. 2016;12:1533-43.

17. Rong Y, Yuan CH, Qu Z, Zhou H, Guan Q, Yang N, Leng XH, Bu L, Wu K, Wang FB. Doxorubicin resistant cancer cells activate myeloid-derived suppressor cells by releasing PGE2. Sci Rep. 2016;6:23824.

18. Cheuk IW, Shin VY, Siu MT, Tsang JY, Ho JC, Chen J, Tse GM, Wang X, Kwong A. Association of EP2 receptor and SLC19A3 in regulating breast cancer metastasis. Am J Cancer Res. 2015;5:3389-33899.

19. Tönisen F, Perrin L, Bayarmagnai B, van den Dries K, Cambi A, Gligorijevic B. EP4 receptor promotes invadopodia and invasion in human breast cancer. Eur J Cell Biol. 2017:S0171-9335:30306-5.

20. Ellis LM, Copeland EM 3rd, Bland KI, Sitren HS. Inhibition of tumor growth and metastasis by chronic intravenous infusion of prostaglandin E1. Ann Surg. 1990;212:45-50.

21. Tabolacci C, Lentini A, Provenzano B, Gismondi A, Rossi S, Beninati S. Similar antineoplastic effects of nimesulide, a selective COX-2 inhibitor, and prostaglandin E1 on B16-F10 murine melanoma cells. Melanoma Res. 2010; 20:273-9.

22. Sagar PS, Das UN. Cytotoxicaction of cis-unsaturated fatty acids on human cervical carcinoma (HeLa) cells in vitro. Prostaglandins Leukotrienes Essent Fatty Acids. 1995;53:287-99.

23. Das UN, Madhavi N. Effect of polyunsaturated fatty acids on drug-sensitive and resistant tumor cells in vitro. Lipids Health Dis. 2011;10:159.

24. Hugo HJ, Saunders C, Ramsay RG, Thompson EW. New Insights on COX-2 in Chronic Inflammation Driving Breast Cancer Growth and Metastasis. J Mammary Gland Biol Neoplasia. 2015;20:109-19.

25. Regulski M, Regulska K, Prukała W, Piotrowska H, Stanisz B, Murias M. COX-2 inhibitors: a novel strategy in the management of breast cancer. Drug Discov Today. 2016;21:598-615

26. Davies G, Martin LA, Sacks N, Dowsett M. Cyclooxygenase-2 (COX-2), aromatase and breast cancer: a possible role for COX-2 inhibitors in breast cancer chemoprevention. Ann Oncol. 2002;13:669-78.

27. Parrett M, Harris R, Joarder F, Ross M, Clausen K, Robertson F. Cyclooxygenase-2 gene expression in human breast cancer. Int J Oncol. 1997;10:503-7.
28. Nassar A, Radhakrishnan A, Cabrero IA, Cotsonis G, Cohen C. COX-2 expression in invasive breast cancer: correlation with prognostic parameters and outcome. Appl Immunohistochem Mol Morphol. 2007;15:255-9.

29. Mao Y, Keller ET, Garfield DH, Shen K, Wang J. Stromal cells in tumor microenvironment and breast cancer. Cancer Metastasis Rev. 2013;32:303-15.

30. Timoshenko AV, Chakraborty C, Wagner GF, Lala PK. COX-2-mediated stimulation of the lymphangiogenic factor VEGF-C in human breast cancer. Br J Cancer. 2006;94:1154-63.

31. Rozic JG, Chakraborty C, Lala PK. Cyclooxygenase inhibitors retard murine mammary tumor progression by reducing tumor cell migration, invasiveness and angiogenesis. Int J Cancer. 2001;93:497-506.

32. Koehne $\mathrm{CH}$, Dubois RN. COX-2 inhibition and colorectal cancer. Semin Oncol. 2004:31:12-21.

33. Knapp DW, Ruple-Czerniak A, Ramos-Vara JA, Naughton JF, Fulkerson CM, Honkisz SIA. Nonselective Cyclooxygenase Inhibitor Enhances the Activity of Vinblastine in a Naturally-Occurring Canine Model of Invasive Urothelial Carcinoma. Bladder Cancer. 2016;2:241-50.

34. Pang LY, Argyle SA, Kamida A, Morrison KO, Argyle DJ. The long-acting COX-2 inhibitor mavacoxib (Trocoxil ${ }^{T M}$ ) has anti-proliferative and proapoptotic effects on canine cancer cell lines and cancer stem cells in vitro. BMC Vet Res. 2014;10:184.

35. Inoue T, Anai S, Onishi S, Miyake M, Tanaka N, Hirayama A, Fujimoto K, Hirao Y. Inhibition of COX-2 expression by topical diclofenac enhanced radiation sensitivity via enhancement of TRAIL in human prostate adenocarcinoma xenograft model. BMC Urol. 2013;13:1.

36. Gasparini G, Gattuso D, Morabito A, Longo R, Torino F, Sarmiento R, Vitale S, Gamucci T, Mariani L. Combined therapy with weekly irinotecan, infusional 5-fluorouracil and the selective COX-2 inhibitor rofecoxib is a safe and effective second-line treatment in metastatic colorectal cancer. Oncologist. 2005;10:710-7.

37. Réti A, Barna G, Pap E, Adleff VL, Komlósi V, Jeney A, Kralovánszky J, Budai B. Enhancement of 5-fluorouracil efficacy on high COX-2 expressing HCA-7 cells by low dose indomethacin and NS-398 but not on low COX-2 expressing HT-29 cells. Pathol Oncol Res. 2009;15:335-44.

38. Lin J, Hsiao PW, Chiu TH, Chao J. Combination of cyclooxygenase-2 inhibitors and oxaliplatin increases the growth inhibition and death in human colon cancer cells. Biochem Pharmacol. 2005;70:658-67.

39. Hawkey CJ, Langman MJS. Non-steroidal anti-inflammatory drugs: overall risks and management. Complementary roles for COX-2 inhibitors and proton pump inhibitors. Gut. 2003;52:600-8. PMCID: PMC1773617

40. Das UN. Can COX-2 inhibitor-induced increase in cardiovascular disease risk be modified by essential fatty acids? J Assoc Physicians India. 2005;53:623-7

41. Howes LG. Selective COX-2 inhibitors, NSAIDs and cardiovascular events - is celecoxib the safest choice? Ther Clin Risk Manag. 2007;3:831-45. PMCID: PMC2376081.

42. Bombardier C, Laine L, Reicin A, Shapiro D, Burgos-Vargas R, Davis B, Day R, Ferraz MB, Hawkey CJ, Hochberg MC, Kvien TK, Schnitzer TJ. VIGOR Study Group. Comparison of upper gastrointestinal toxicity of rofecoxib and naproxen in patients with rheumatoid arthritis. VIGOR Study Group. N Engl J Med. 2000;343:1520-8

43. Yu Q, Purwaha P, Ni K, Sun C, Mallik S, Qian SY. Characterization of novel radicals from COX-catalyzed arachidonic acid peroxidation. Free Radic Biol Med. 2009:47:568-76. PMCID: PMC2716437.

44. Xiao Y, Gu Y, Purwaha P, Ni K, Law B, Mallik S, Qian SY. Characterization of free radicals formed from COX-catalyzed DGLA peroxidation. Free Radic Bio Med. 2011;50:1163-70. PMCID: PMC3073824.

45. Gu Y, Xu Y, Law B, Qian SY. The first characterization of free radicals formed from cellular COX-catalyzed peroxidation. Free Radic Biol Med. 2013;57:49-60

46. Xu Y, Qi J, Yang XY, Wu E, Qian SY. Free radical derivatives formed from COX-catalyzed DGLA peroxidation can attenuate colon cancer cell growth and enhance 5-FU's cytotoxicity. Redox Biol. 2014:2:610-8.

47. Xu Y, Yang XY, Zhao PJ, Yang ZY, Yan CH, Guo B, Qian SY. Knockdown of delta-5-desaturase promotes the anti-cancer activity of dihomo- $\gamma$-linolenic acid and enhances the efficacy of chemotherapy in colon cancer cells expressing COX-2. Free Radic Biol Med. 2016;96:67-77.

48. Yang X, Xu Y, Brooks A, Guo B, Miskimins KW, Qian SY. Knockdown delta5 -desaturase promotes the formation of a novel free radical byproduct from COX-catalyzed $\omega-6$ peroxidation to induce apoptosis and sensitize pancreatic cancer cells to chemotherapy drugs. Free Radic Biol and Med. 2016;97:342-50 
49. Yang X, Xu Y, Wang T, Shu D, Guo P, Miskimins KW, Qian SY. Inhibition of cancer migration and invasion by knocking down delta-5-desaturase in COX-2 overexpressed cancer cells. Redox Biol. 2017;11:653-62.

50. Quehenberger O, Armando A, Dumlao D, Stephens DL, Dennis EA. Lipidomics analysis of essential fatty acids in macrophages. Prostaglandins Leukot Essent Fatty Acids. 2008;79:123-9.

51. Adamsen BL, Kravik KL, De Angelis PM. DNA damage signaling in response to 5-fluorouracil in three colorectal cancer cell lines with different mismatch repair and TP53 status. Int J Oncol. 2011;39:673-82.

52. Thant AA, Wu Y, Lee J, Mishra DK, Garcia H, Koeffler HP, Vadgama JV. Role of Caspases in 5-FU and Selenium Induced Growth Inhibition of Colorectal Cancer Cells. Anticancer Res. 2008;28:3579-92.

53. Zhu P, Zhao N, Sheng D, Hou J, Hao C, Yang X, Zhu B, Zhang S, Han Z, Wei L, Zhang L. Inhibition of Growth and Metastasis of Colon Cancer by Delivering 5-Fluorouracil-loaded Pluronic P85 Copolymer Micelles. Sci Rep. 2016;6:20896.

54. Shakibaei M, Kraehe P, Popper B, Shayan P, Goel A, Buhrmann C. Curcumin potentiates antitumor activity of 5 -fluorouracil in a $3 \mathrm{D}$ alginate tumor microenvironment of colorectal cancer. BMC Cancer. 2015;15:250.

55. Peng ZR, Zhong WH, Liu J, Xiao PT. Effects of the combination of hyperbaric oxygen and 5-fluorouracil on proliferation and metastasis of human nasopharyngeal carcinoma CNE-2Z cells. Undersea Hyperb Med. 2010;37:141-50.

56. Iovieno A, Lambiase A, Moretti C, Perrella E, Bonini S. Therapeutic effect of topical 5 -fluorouracil in conjunctival squamous carcinoma is associated with changes in matrix metalloproteinases and tissue inhibitor of metalloproteinases expression. Cornea. 2009;28:821-4.

57. Buhrmann C, Shayan P, Kraehe P, Popper B, Goel A, Shakibaei M. Resveratrol induces chemosensitization to 5 -fluorouracil through up-regulation of intercellular junctions, Epithelial-to-mesenchymal transition and apoptosis in colorectal cancer. Biochem Pharmacol. 2015;98:51-68.

58. Chu L, Sutton LM, Peterson BL, Havlin KA, Winer EP. Continuous infusion 5-fluorouracil as first-line therapy for metastatic breast cancer. J Infus Chemother. 1996;6:211-6.

59. Noordhuis P, Holwerda U, Van der Wilt CL, Van Groeningen CJ, Smid K, Meijer S, Pinedo HM, Peters GJ. 5-Fluorouracil incorporation into RNA and DNA in relation to thymidylate synthase inhibition of human colorectal cancers. Ann Oncol. 2004;15:1025-32.

60. Chan JY, Phoo MS, Clement MV, Pervaiz S, Lee SC. Resveratrol displays converse dose-related effects on 5-fluorouracil-evoked colon cancer cell apoptosis: the roles of caspase-6 and p53. Cancer Biol Ther. 2008;7:1305-12.

61. Qin L, Zhang X, Zhang L, Feng Y, Weng GX, Li MZ, Kong QL, Qian CN, Zeng YX, Zeng MS, Liao DF, Song LB. Downregulation of BMI-1 enhances 5fluorouracil-induced apoptosis in nasopharyngeal carcinoma cells. Biochem Biophys Res Commun. 2008;371:531-5.

62. Li MH, Ito D, Sanada M, Odani T, Hatori M, Iwase M, Nagumo M. Effect of 5-fluorouracil on G1 phase cell cycle regulation in oral cancer cell lines. Oral Oncol. 2004;40:63-70.

63. Zhang N, Yin Y, Xu SJ, Chen WS. 5-Fluorouracil: mechanisms of resistance and reversal strategies. Molecules. 2008;13:1551-69.

64. Li X, Wang S, Li Z, Long X, Guo Z, Zhang G, Zu J, Chen Y, Wen L. NEAT induces epithelial-mesenchymal transition and 5-FU resistance through the miR-129/ZEB2 axis in breast cancer. FEBS Lett. 2016; Epub ahead of print

65. Fantozzi A, Christofori G. Mouse models of breast cancer metastasis. Breast Cancer Res. 2006;8:212.

66. Zhuang Y, Chan DK, Haugrud AB, Miskimins WK. Mechanisms by which low glucose enhances the cytotoxicity of metformin to cancer cells both in vitro and in vivo. PLoS One. 2014;9:e108444.

67. Shu D, Shu Y, Haque F, Abdelmawla S, Guo P. Thermodynamically stable RNA three-way junction for constructing multifunctional nanoparticles for delivery of therapeutics. Nat Nanotechnol. 2011;6:658-67.

68. Cui D, Zhang C, Liu B, Shu Y, Du T, Shu D, Wang K, Dai F, Liu Y, Li C, Pan F Yang Y, Ni J, Li H, Brand-Saberi B, Guo P. Regression of Gastric Cancer by Systemic Injection of RNA Nanoparticles Carrying both Ligand and siRNA. Sci Rep. 2015:5:10726.

69. Shu D, Li H, Shu Y, Xiong G, Carson WE 3rd, Haque F, Xu R, Guo P. Systemic Delivery of Anti-miRNA for Suppression of Triple Negative Breast Cancer Utilizing RNA Nanotechnology. ACS Nano. 2015;9:9731-40.

70. Mustafi R, Dougherty U, Shah H, Dehghan H, Gliksberg A, Wu J, Zhu H, Joseph L, Hart J, Dive C, Fichera A, Threadgill D, Bissonnette M. Both stromal cell and colonocyte epidermal growth factor receptors control HCT116 colon cancer cell growth in tumor xenografts. Carcinogenesis. 2012;33: 1930-9.

\section{Submit your next manuscript to BioMed Central and we will help you at every step:}

- We accept pre-submission inquiries

- Our selector tool helps you to find the most relevant journal

- We provide round the clock customer support

- Convenient online submission

- Thorough peer review

- Inclusion in PubMed and all major indexing services

- Maximum visibility for your research

Submit your manuscript at www.biomedcentral.com/submit
Biomed Central 